\title{
Genetic parameters for carcass traits and body size of meat sheep ${ }^{1}$
}

\section{Parâmetros genéticos para características de carcaça e tamanho corporal em ovinos de corte}

\author{
Luciano Silva Sena ${ }^{2 *}$; Gleyson Vieira dos Santos'; Tatiana Saraiva Torres ${ }^{2}$; \\ Antônio de Sousa Júnior ${ }^{3}$; Aurino de Araujo Rego Neto²; \\ José Lindenberg Rocha Sarmento ${ }^{4}$; Daniel Biagiotti ${ }^{5}$
}

\begin{abstract}
The present study aimed to estimate variance components and heritability coefficients $\left(\mathrm{h}^{2}\right)$ in Santa Inês sheep by single- and two-trait analyses for the traits loin eye area (LEA), length (LEL) and maximum depth (LED), in the longissimus dorsi muscle, subcutaneous fat thickness (SFT), fat thickness over the biceps femoris muscle (FTBF), croup height $(\mathrm{CH})$, thoracic circumference (TC), thoracic depth (TD), body length (BL), and adult live weight (ALW). The restricted maximum likelihood (REML) was used to estimate variance components in an animal model. In both types of analyses, we estimated moderate heritability for all traits, with the exception of SFT, CH, TC, BL, and ALW (all of which yielded low $\mathrm{h}^{2}$ estimates). In two-trait analysis for body size, only TD yielded a lower $\mathrm{h}^{2}$ estimate, when compared to single-trait analysis. On the other hand, $\mathrm{CH}, \mathrm{TC}$, and $\mathrm{BL}$ yielded higher $\mathrm{h}^{2}$ estimates. Most estimates for variance components and $\mathrm{h}^{2}$ in two-trait analysis were higher than those in single-trait analysis. This finding suggests the possibility of a moderate response to selection for improvement in the carcass of meat sheep using the specific carcass traits evaluated (except SFT), highlighting LEA. The fat thickness over the biceps femoris muscle showed higher potential for response to direct selection for fat deposition than SFT. Thoracic depth showed higher potential for response to direct selection for body size than the other morphometric measurements. In the present study, adult live weight was not an effective criterion for direct selection.
\end{abstract}

Key words: Animal model. Heritability. Longissimus dorsi. Morphometry. Selection. Variance components.

\section{Resumo}

Objetivou-se com esta pesquisa estimar componentes de variância e coeficientes de herdabilidade $\left(\mathrm{h}^{2}\right)$ por análises uni e bicaracterística para as características área (AOL), comprimento (COL) e profundidade máxima (POL) de olho de lombo, no músculo longissimus dorsi, espessura de gordura subcutânea (EGS), espessura de gordura do músculo biceps femoris (EGBF), altura da garupa (AG), circunferência torácica $(\mathrm{CT})$, profundidade torácica $(\mathrm{PT})$, comprimento corporal $(\mathrm{CC})$ e peso vivo à idade adulta $(\mathrm{PA})$, em ovinos Santa Inês. Foi utilizado modelo animal pela metodologia da máxima verossimilhança

${ }^{1}$ Parte da Dissertação de Mestrado do primeiro autor.

2 Discentes do Curso de Doutorado do Programa de Pós-Graduação em Ciência Animal, Universidade Federal do Piauí, UFPI, Teresina, PI, Brasil. E-mail: lucianossbj@hotmail.com; gleysonvieira@zootecnista.com.br; tatianaana@hotmail.com; aurinorego@hotmail.com

${ }^{3}$ Prof. Dr., Colégio Técnico de Teresina, Setor de Biotecnologia, UFPI, Teresina, PI, Brasil. E-mail: sousajunior@ufpi.edu.br

${ }^{4}$ Dr., Pesquisador do CNPq, Dept ${ }^{\circ}$ de Zootecnia, UFPI, Teresina, PI, Brasil. E-mail: sarmento@ufpi.edu.br

${ }^{5}$ Prof. Dr., Colégio Técnico de Bom Jesus, UFPI, Bom Jesus, PI, Brasil. E-mail: biagiotti@ufpi.edu.br

* Author for correspondence 
restrita (REML). Estimou-se herdabilidade moderada para as características, nos dois tipos de análise, exceto para EGS, AG, CT, CC e PA, para as quais as estimativas foram de baixa magnitude. Nas análises bicaracterísticas para tamanho corporal, apenas PT apresentou menor estimativa de $\mathrm{h}^{2}$, quando comparado com a análise unicaracterística, enquanto que $\mathrm{AG}, \mathrm{CT}$ e $\mathrm{CC}$ apresentaram valores maiores. Nas análises bicaracterísticas, a maioria das estimativas de componentes de variância e $\mathrm{h}^{2}$ foram superiores àquelas obtidas nas análises unicaracterística, o que evidencia a possibilidade de resposta moderada à seleção para melhoria da carcaça em ovinos de corte usando as características de carcaça avaliadas, com exceção de EGS e com destaque para área de olho de lombo. A espessura de gordura do músculo biceps femoris apresentou maior potencial para resposta à seleção direta para deposição de gordura na carcaça comparado a EGS. A profundidade torácica demonstrou maior potencial de resposta à seleção direta para tamanho corporal entre as medidas morfométricas estudadas. $\mathrm{O}$ peso vivo à idade adulta não demonstrou neste estudo ser um bom critério para seleção direta.

Palavras-chave: Componentes de variância. Herdabilidade. Longissimus dorsi. Modelo animal. Morfometria. Seleção.

\section{Introduction}

Genetic improvement of a breed for meat production can be achieved through genetic evaluation of animals in growth-related traits and selection of genetically superior individuals. However, effective genetic evaluation is dependent on the availability of accurate estimates of genetic parameters of the traits of interest, which depend on several factors. These factors include the quantity of data available, the statistical model applied, the method of estimation of (co)variance components, and the genetic parameters evaluated (SARMENTO et al., 2006).

It is important to include fixed and random effects that best match biological reality, for more accurate estimation of genetic parameters. Thus, the process by which contemporary groups are formed should take as many effects as possible into consideration, to include valid data that would be applicable to a greater number of animals.

Single-trait analysis entails the analysis of just one trait at a time. However, according to Vicini (2005), the use of two-trait analyses permits a greater number of observations, due to values derived from relationships between animals in various traits that yield greater additive genetic variance. In comparison to single-trait analysis, two-trait analysis facilitates more precise estimation of genetic parameters and greater accuracy of assessments, owing to the effects of genes that act simultaneously on two traits (PEREIRA, 2004).

Thus, to determine more accurately the potential for genetic improvement of the carcass of sheep in response to specific selection criteria, the present study aimed to compare estimates of variance components and heritability coefficients for carcass and body size traits, based on single- and two-trait analyses.

\section{Materials and Methods}

Santa Inês sheep $(1,306)$ from sixteen farms in the states of Piauí and Maranhão, Brazil, were selected based on a relationship matrix. All animals were registered with the Brazilian Sheep Breeders Association (ARCO) and raised in a semi-intensive system. They received supplemented feed when pasture was in short supply. Data on adult ewes were collected between January 2012 and April 2014.

Carcass composition was evaluated based on the following traits: loin eye area (LEA), measured in $\mathrm{cm}^{2}$; loin eye length (LEL) and loin eye maximum depth (LED), which is indicative of the extent of carcass muscling, both measured in $\mathrm{cm}$; subcutaneous fat thickness (SFT), measured in $\mathrm{mm}$; and fat thickness over the biceps femoris muscle (FTBF), measured in mm. Carcass traits were evaluated via ultrasound images of the cross 
section of the longissimus dorsi muscle between the $12^{\text {th }}$ and $13^{\text {th }}$ lumbar vertebrae, using an ultrasound device model KX2000G VET, equipped with a 3.5 $\mathrm{MHz}$ linear transducer. Images were viewed and immediately interpreted. For the best image quality, and in the interest of animal welfare, sheep were restrained in a normal, comfortable standing position.

Body size of the animals was evaluated based on the following traits: croup height $(\mathrm{CH})$, measured from the sacral tuberosity of the ilium to the ground; thoracic circumference (TC), measured at the outer circumference of the thoracic cavity, near the axilla; thoracic depth (TD), calculated as the difference between height at the withers and that at the sternum; and body length (BL), measured from the cranial portion of the greater tuberosity of the humerus to the caudal portion of the ischial tuberosity. All data related to morphometry were measured in centimeters $(\mathrm{cm})$, with the animal in a standing position. Adult live weight (ALW) was measured in $\mathrm{kg}$ using a pendulum-type scale.

Following consistency analysis, a file was created that contained data on animals, parents, contemporary groups (defined by a combination of the farm of origin, year of birth, birth season, and collection period), year of collection, age class and type of birth, as well as observations on carcass traits and body weight and size. Values within three standard deviations above or below the mean of the respective contemporary group were eliminated. The numerator relationship matrix of Wright's inbreeding coefficients contained 1,306 animals.

Single- and two-trait analyses were performed using the following animal model:

$$
\mathrm{y}=\mathrm{X} \beta+\mathrm{Z} \alpha+\mathrm{e}
$$

where $y$ is the vector of observations of the traits measured (carcass, body size, and body weight); $\beta$ is the vector of fixed effects, formed by contemporary groups, year of data collection, type of birth, and age class of the animal at the time of collection (three classes: the first comprising animals $\leq$ two years of age; the second, comprising animals $>$ two to four years of age; and the third, comprising animals $>$ four years of age); $\alpha$ is the vector of random effects, which is the direct additive genetic value of each animal; e is the vector of random errors; $X$ is the incidence matrix that associates $\beta$ with $y$; and $\mathrm{Z}$ is the incidence matrix of random effects.

The subscripts 1 and 2 were used for traits that were analyzed simultaneously (as shown in the following model):

$$
\begin{aligned}
& \mathbf{E}\left[\begin{array}{l}
y_{1} \\
y_{2}
\end{array}\right]=\left[\begin{array}{l}
X_{1} \beta \\
X_{2} \beta
\end{array}\right] \\
& \operatorname{Var}=\left[\begin{array}{l}
\alpha \\
\mathrm{e}
\end{array}\right]=\left[\begin{array}{cccc}
\mathrm{A}_{\sigma_{\mathrm{s}_{1}}^{2}} & \mathrm{~A}_{\sigma_{\mathrm{s}_{1} \mathrm{a}_{2}}} & 0 & 0 \\
\mathrm{~A}_{\sigma_{\mathrm{s}_{1} \mathrm{a}_{2}}} & \mathrm{~A}_{\sigma_{\mathrm{s}_{2}}^{2}} & 0 & 0 \\
0 & 0 & \mathrm{I}_{\mathrm{N}} \sigma_{\mathrm{e}_{1}}^{2} & \mathrm{I}_{\mathrm{N}} \sigma_{\mathrm{e}_{1} \mathrm{e}_{2}} \\
0 & 0 & \mathrm{I}_{\mathrm{N}} \sigma_{\mathrm{e}_{1} \mathrm{e}_{2}} & \mathrm{I}_{\mathrm{N}} \sigma_{\mathrm{e}_{2}}^{2}
\end{array}\right] \\
& \mathbf{E}\left[\begin{array}{l}
y_{1} \\
y_{2}
\end{array}\right]=\left[\begin{array}{l}
X_{1} \beta \\
X_{2} \beta
\end{array}\right]
\end{aligned}
$$

where $\sigma_{\mathrm{a}_{1}}^{2}$ represents the direct additive genetic variance for trait $1 ; \sigma_{\mathbf{a}_{\mathbf{2}}}^{\mathbf{2}}$ represents the direct additive genetic variance for trait $2 ; \sigma_{\theta}^{2}$ represents residual variance (traits 1 and 2); $\sigma_{\mathrm{a}_{1} \mathrm{a}_{2}}$ represents the additive genetic covariance between direct effects of traits 1 and $2 ; \sigma_{\varepsilon_{1} \varepsilon_{2}}$ represents the covariance between residual effects of traits 1 and 2; A represents the numerator relationship matrix of Wright's inbreeding coefficient; $\mathrm{N}$ represents the number of observations; and I represents the identity matrix of order equal to the number of animals with observations.

Two-trait analyses of the ten traits were performed, each of which was composed by the combination of one trait with the remaining nine. Thus, estimates of the variance components of a certain trait were calculated as the average of all analyses that included that trait as the first in the pair.

Components of (co)variance and genetic parameters were estimated using the restricted maximum likelihood (REML) method and 
the Wombat software (MEYER, 2006). The convergence criterion used was $10^{-7}$.

\section{Results and Discussion}

The mean loin eye area (LEA) observed in the present study (Table 1) was lower than that reported in other studies on in vivo carcass evaluation of adult Santa Inês sheep. Pinheiro et al. (2010) reported a mean LEA of $8.86 \mathrm{~cm}^{2}$ in culled ewes of this same breed. There is a considerable range of values for this trait, and this may be due to genetic variability among animals, since genetic research on the Santa Inês breed has not been extensive. In addition, management methods differed from one farm to the next.

Table 1. Descriptive statistics of carcass, body size, and body weight traits in Santa Inês sheep.

\begin{tabular}{lccccc}
\hline Trait & $\mathrm{N}$ & Mean $(\mathrm{SD})$ & $\mathrm{CV}$ & Minimum & Maximum \\
\hline LEA $\left(\mathrm{cm}^{2}\right)$ & 677 & $8.70(4.82)$ & 55.40 & 2.17 & 25.05 \\
LEL $(\mathrm{cm})$ & 677 & $4.61(0.85)$ & 18.44 & 2.16 & 6.91 \\
LED $(\mathrm{cm})$ & 677 & $2.67(0.56)$ & 20.97 & 1.15 & 4.88 \\
FTBF $(\mathrm{mm})$ & 663 & $1.15(0.95)$ & 82.61 & 0.00 & 10.54 \\
SFT $(\mathrm{mm})$ & 645 & $1.88(1.15)$ & 61.17 & 0.00 & 11.11 \\
TD $(\mathrm{cm})$ & 703 & $34.66(3.32)$ & 9.60 & 26.50 & 48.50 \\
TC $(\mathrm{cm})$ & 703 & $92.99(9.79)$ & 10.52 & 51.00 & 128.00 \\
BL $(\mathrm{cm})$ & 703 & $76.20(5.18)$ & 6.80 & 62.00 & 97.00 \\
CH $(\mathrm{cm})$ & 703 & $75.89(3.69)$ & 4.86 & 61.00 & 89.00 \\
ALW $(\mathrm{kg})$ & 548 & $57.99(14.29)$ & 24.64 & 20.40 & 119.20 \\
\hline
\end{tabular}

LEA - loin eye area; LEL - loin eye length; LED - loin eye maximum depth; FTBF - fat thickness over the biceps femoris; SFT subcutaneous fat thickness; TD - thoracic depth; TC - thoracic circumference; BL - body length; CH - croup height; ALW - adult live weight.

Pinheiro et al. (2014) used ultrasonography to measure the length of the longissimus dorsi in Santa Inês sheep and reported a mean of $5.19 \mathrm{~cm}$. This value is greater than the mean value obtained in the present study, although it falls within our range of values, that is, a minimum of $2.16 \mathrm{~cm}$ and maximum of $6.91 \mathrm{~cm}$. According to the findings of Pinheiro et al. (2010), who used ultrasound to make in vivo measurements, the length of the longissimus dorsi muscle of sheep is highly correlated with LEA. This suggests that the same set of genes can act on the expression of these two traits simultaneously.

Pinheiro et al. (2014) also reported a mean loin eye depth (LED) of $2.45 \mathrm{~cm}$, which was similar to that observed in the present study (Table 1). Those authors reported a correlation of 0.84 between LED and LEA in culled Santa Inês ewes, whereas
Figueiredo Filho et al. (2012) reported a correlation of 0.71 between the same traits in goats. These findings further corroborate the theory that the dimensions of the longissimus dorsi are possibly expressed by the same genes.

Few studies have evaluated the fat thickness over the biceps femoris muscle (FTBF) in sheep. It is evident however, that this trait varies widely, considering the coefficient of variation and the range of values observed in the present study ( 0 to $10.54 \mathrm{~mm}$ ) (Table 1).

The mean subcutaneous fat thickness (SFT) in the present study (Table 1) was lower than that reported by Suguisawa et al. (2009) $(3.00 \mathrm{~mm})$. However, wide range of values (0 to $11.11 \mathrm{~mm}$ ) was observed for this trait. This finding is indicative 
of high variance among the animals of the present study, both in terms of nutritional management and physiological status. SFT is highly influenced by the physiological and nutritional conditions of the animal at the time of evaluation.

The mean thoracic depth (TD) in the present study was very close to that observed by Figueiredo Filho et al. (2013), who compared adult Santa Inês ewes based on classes of thoracic circumference (TC) and reported a mean of $34.46 \mathrm{~cm}$ for animals of a larger class. This class comprised individuals with a thoracic circumference greater than $83.50 \mathrm{~cm}$, and a favourable relation was evident between TD and $\mathrm{TC}$, both of which directly influence the live weight of the animal. This finding is corroborated by Costa Júnior et al. (2006), who reported high correlation (0.94) between TC and body weight, in Santa Inês sheep. Cam et al. (2010) studied the relationship between live weight and body measurements and reported that TD was highly correlated $(0.88)$ with live weight in Karayaka sheep. These findings suggest that TD can be used when selecting animals for higher body weight, which would likely produce a higher carcass yield.

The mean value observed for TC in the present study was higher than the mean of $84.64 \mathrm{~cm}$ reported by Pinheiro and Jorge (2010) in culled Santa Inês ewes. The animals in that study were reared in an intensive system and their mean age was six years. The mean TC observed in the present study was also higher than the mean of $86.40 \mathrm{~cm}$ reported by Biagiotti et al. (2015) in Santa Inês ewes raised among several flocks of sheep in the state of Piauí. According to Silva (2007), a higher TC is indicative of a greater capacity of the animal to gain weight, owing to higher respiratory capacity and dry matter intake.

Body length (BL) and croup height $(\mathrm{CH})$ yielded similar values, with means of 76.20 and $75.89 \mathrm{~cm}$, respectively (Table 1). These values are higher than those reported by Biagiotti et al. (2015) (70.27 and $71.37 \mathrm{~cm}$, for $\mathrm{BL}$ and $\mathrm{CH}$, respectively). Salako (2006) reported correlations of 0.76 and 0.77 between $\mathrm{BL}$ and $\mathrm{CH}$ in adult West African Dwarf (WAD) and Yankasa sheep, respectively, both of which are phenotypically similar to Santa Inês sheep. Furthermore, these high correlations show a consistent pattern of development in larger sheep. Pinheiro and Jorge (2010) reported a correlation of 0.58 between BL and $\mathrm{CH}$ in Santa Inês ewes. According to these authors, the proximity within the range of values observed for $\mathrm{BL}$ and $\mathrm{CH}$, and correlations from moderate to high magnitude between the mean values for these two traits suggest that animals are generally of the same size. Some authors point out that this factor is very important in the accurate determination of other biometric measurements both of the carcass and in vivo.

Adult live weight (ALW) yielded a high coefficient of variation and high amplitude (Table 1), owing to differences in body conformation and nutritional status of animals. ALW mean value observed in the present study was similar to those reported by Costa Júnior et al. (2006) in ewes raised in Teresina and Campo Maior, in the state of Piauí; that is, $34.6,46.6$, and $81.3 \mathrm{~kg}$, in sheep reared in management systems of low, medium, and high levels of technical efficiency, respectively.

In comparison to estimates of additive genetic variance in single-trait analysis, estimates in twotrait analysis were similar for LEL and LED, slightly lower for TD, and higher for all other traits evaluated (Table 2). It is noteworthy that two-trait analysis facilitated more accurate assessment and precise estimations of genetic parameters, when compared to single-trait analysis. This could be attributed to the expression of genes that act simultaneously on two traits, thereby enhancing the genetic parameters estimation for the trait of interest (CARVALHO et al., 2014). 
Table 2. Estimates of variance components and heritability coefficients for carcass, body size, and body weight traits in Santa Inês sheep using single- and two-trait analyses.

\begin{tabular}{ccccccccccc}
\hline Variance components and $\mathrm{h}^{2}$ & LEA & LEL & LED & FTBF & SFT & TD & TC & BL & CH & ALW \\
\hline Single-trait analysis & & & & & & & & & & \\
$\sigma_{\mathbf{a}}^{\mathbf{2}}$ & 1.58 & 0.10 & 0.05 & 0.12 & 0.02 & 1.79 & 6.03 & 1.65 & 0.74 & 27.66 \\
$\sigma^{\mathbf{2}} \mathbf{e}$ & 6.29 & 0.24 & 0.14 & 0.39 & 0.68 & 6.72 & 47.79 & 15.44 & 6.79 & 114.08 \\
$\sigma_{\mathbf{p}}^{\mathbf{2}}$ & 7.87 & 0.34 & 0.19 & 0.51 & 0.70 & 8.51 & 53.82 & 17.09 & 7.53 & 141.74 \\
$\mathbf{h}^{\mathbf{2}}$ & 0.20 & 0.29 & 0.26 & 0.23 & 0.02 & 0.21 & 0.11 & 0.09 & 0.09 & 0.19 \\
\hline Two-trait analysis & & & & & & & & & & \\
$\sigma_{\mathbf{a}}^{\mathbf{2}}$ & 1.67 & 0.10 & 0.05 & 0.14 & 0.08 & 1.74 & 7.12 & 1.95 & 0.82 & 27.93 \\
$\sigma^{\mathbf{2}} \mathbf{e}$ & 6.84 & 0.26 & 0.16 & 0.39 & 0.65 & 6.78 & 46.85 & 15.18 & 6.72 & 128.92 \\
$\sigma^{\mathbf{2}} \mathbf{p}$ & 8.51 & 0.36 & 0.21 & 0.53 & 0.73 & 8.52 & 53.97 & 17.13 & 7.54 & 156.85 \\
$\mathbf{h}^{\mathbf{2}}$ & 0.20 & 0.27 & 0.23 & 0.26 & 0.11 & 0.20 & 0.13 & 0.11 & 0.11 & 0.18 \\
\hline
\end{tabular}

LEA - loin eye area; LEL - loin eye length; LED - loin eye maximum depth; FTBF - fat thickness over the biceps femoris; SFT - subcutaneous fat thickness; TD - thoracic depth; TC - thoracic circumference; BL - body length; CH - croup height; ALW adult live weight; $\sigma^{\mathbf{2}} \mathbf{a}$ - additive genetic variance; $\sigma^{\mathbf{2}} \mathbf{e}$ - environmental variance; $\sigma^{\mathbf{2}} \mathbf{p}$ - phenotypic variance; $\mathbf{h}^{2}-$ heritability coefficients.

The heritability $\left(\mathrm{h}^{2}\right)$ estimates for LEA in both types of analysis were moderate (Table 2). This finding suggests that the phenotype is a good indicator of the genotype for this trait, and indicates the possibility to achieve genetic gains through direct selection of LEA in the study population.

Estimated heritability values for LEA in single- and two-trait analyses were similar. On the other hand, a slight increase (which favors genetic improvement) was noted in the estimates of variance components in two-trait analysis. The similarity noted between $\mathrm{h}^{2}$ estimates using different models corroborate the findings of Giné et al. (2004), who reported no difference in heritability estimates for LEA and other carcass traits of pigs, subjected to single- and two-trait analyses. Faria et al. (2015) reported $h^{2}$ estimates of 0.25 and 0.30 for LEA in cattle using single- and two-trait analyses, respectively. Their findings indicate that genetic variance may be underestimated when single-trait analysis is used.
Variance components for LEL and LED differed slightly between the two types of analyses (Table $2)$. Nevertheless, because similar values for additive genetic variance and slight increase in environmental and phenotypic variance were also noted, a slight decrease in $\mathrm{h}^{2}$ estimates for both traits was observed in two-trait analysis. Environment, sample size, and estimation method are among the factors that could be influencing the increase in values of those variance components and consequently, the change in $\mathrm{h}^{2}$ estimates. In the present study, $\mathrm{h}^{2}$ estimates for LED were consistent with the findings of Mortimer et al. (2010), who reported $\mathrm{h}^{2}$ estimate of 0.25 for LED using ultrasound in the Merino breed.

SFT and FTBF yielded low and moderate $\mathrm{h}^{2}$ estimates (Table 2), respectively. The values observed in the present study were lower than those reported by Figueiredo Filho et al. (2015), who estimated $h^{2}$ of 0.11 for SFT and 0.33 for fat thickness over the croup (which is equivalent to FTBF) in Santa Inês sheep using single-trait analysis. The 
aforementioned study reported higher $\mathrm{h}^{2}$ estimates of 0.29 for SFT and 0.36 for FTBF when multi-trait (three-trait) analysis was used. These findings are consistent with those of the present study, as our $\mathrm{h}^{2}$ estimates for SFT and FTBF were also higher in two-trait analysis than they were in single-trait analysis.

The additive genetic variance for FTBF was higher than that for SFT (Table 2) in both types of analysis in the present study. This suggests that the trait of fat thickness is more effectively measured in the muscles of the croup, where it can be a more practical selection criterion in breeding programs owing to an increased additive genetic component.

Lima Neto et al. (2009) reported a genetic correlation of 0.64 between fat thickness over the rib and over the croup in a study that estimated genetic parameters for carcass traits in Guzerat cattle using ultrasound. According to those authors, subcutaneous fat deposition was evident both over the croup and at the loin eye area. Wilson et al. (2001) estimated a genetic correlation of 0.74 between these two traits in a study conducted with Bos taurus. Based on the results of those authors and the differences noted between variances in the present study, measurement of FTBF has advantages over that of the lower back, because it represents a combination of phenotypic variability and higher additive genetic variance.

Because SFT and FTBF undergo little genetic and environmental variation, the estimates of variance components for carcass traits in the present study showed slight variation even with different types of analysis. SFT was one exception however, as its genetic variance increased fourfold in twotrait analysis. This finding could be attributed to increased sensitivity of adipose tissue to environmental conditions.

SFT and BFFT $h^{2}$ estimates were higher in twotrait analysis than they were in single-trait analysis. Residual and phenotypic variances for SFT were similar in single- and two-trait analyses (Table 2).
Heritability estimate for SFT in single-trait analysis (0.02) was lower than that observed by Ono (2011), who reported an $\mathrm{h}^{2}$ estimate of 0.15 for SFT when estimated heritability coefficients for carcass traits of adult crossbred sheep. These findings corroborate the facts that SFT is a trait with low heritability that is sensitive to environmental effects, such as nutritional management, which directly affects subcutaneous fat deposition in animals.

Yokoo et al. (2008) reported heritability estimates of 0.35 and 0.52 for loin eye area and subcutaneous fat thickness, respectively, in Nellore cattle of Brazil. Different $h^{2}$ values for the same trait are estimated in different researches because heritability is a specific parameter specific to each population. In addition, variations in the number of observations within each population, the methods of measurement of the traits of interest, and methods of estimation can all influence the results.

Heritability estimates for TD yielded moderate values in both types of analyses (Table 2). However, other body size traits (TC, BL, and $\mathrm{CH}$ ), yielded low $\mathrm{h}^{2}$ estimates. These findings could be attributed to the homogeneity in the body size and in most cases, similar ages of the animals. In the present study, TC is the body size trait that showed higher additive genetic variation, yet this trait is greatly affected by environmental variation. This was evident from the estimates of environmental variance for TC that were among the largest in the present study, which directly increased phenotypic variance, and consequently, decreased the heritability estimate for this trait.

The heritability estimates in the present study (Table 2) yielded low values for adult live weight (ALW), a finding that is consistent with that reported by Karamichou et al. (2007), who estimated $h^{2}$ of 0.19 , in sheep. These estimates indicate that direct selection based on live weight might not be effective, because various components that are not directly related to carcass characteristics contribute to the live weight of an animal. 


\section{Conclusions}

The use of single- and two-trait analyses in the present study, yielded similar heritability estimates for most traits. However, most estimates were higher in two-trait analysis than in single-trait analysis, suggesting a higher accuracy with twotrait analysis, which could be attributed to the combination of traits considered in the estimation of variance components.

The moderate heritability estimates for carcass traits (with the exception of SFT), demonstrated a moderate potential for response to direct selection of these traits. Among the measurements of the longissimus dorsi considered, LEA should be crucial for selection, owing to its high additive genetic variation. Regarding subcutaneous fat deposition, FTBF has considerable potential for response to direct selection. Among the body size traits under investigation, TD has the greatest potential for response to direct selection, owing to its comparatively larger estimates of additive genetic variance. In contrast, ALW is not an effective criterion for direct selection.

\section{References}

BIAGIOTTI, D.; SARMENTO, J. L. R.; REGO NETO, A. A.; SANTOS, N. P. S.; FIGUEIREDO FILHO, L. A. S.; SANTOS, G. V.; TORRES, T. S.; SENA, L. S. Diferenciação de populações ovinas encontradas no estado do Piauí. Archivos de Zootecnia, Córdoba, v. 64, n. 245 , p. $5-12,2015$.

CAM, M. A.; OLFAZ, M.; SOYDAN, E. Body measurements reflect body weights and carcass yields in Karayaka Sheep. Asian Journal of Animal and Veterinary Advances, Dubai, v. 5, n. 2, p. 120-127, 2010.

CARVALHO, G. C.; BARBOSA, L. T.; OLIVEIRA, T. M.; FONSECA, F. E. P.; MUNIZ, E. N.; AZEVEDO, H. C. Estimação de parâmetros genéticos de ovinos da raça Santa Inês utilizando modelos uni e bicaracterística. Ciência Rural, Santa Maria, v. 44, n. 1, p. 111-116, 2014.

COSTAJÚNIOR, G. S.; CAMPELO, J.E. G.;AZEVÊDO, D. M. M. R.; MARTINS FILHO, R.; CAVALCANTE, R. R.; LOPES, J. B.; OLIVEIRA, M. E. Caracterização morfométrica de ovinos da raça Santa Inês criados nas microrregiões de Teresina e Campo Maior, Piauí. Revista Brasileira de Zootecnia, Viçosa, MG, v. 35, n. 6, p. 22602267, 2006.

FARIA, C. U.; ANDRADE, W. B. F.; PEREIRA, C. F.; SILVA, R. P.; LÔBO, R. B. Análise bayesiana para características de carcaça avaliadas por ultrassonografia de bovinos da raça Nelore Mocho, criados em bioma Cerrado. Ciência Rural, Santa Maria, v. 45, n. 2, p. 317322, 2015.

FIGUEIREDO FILHO, L. A. S.; DO Ó, A. O.; SARMENTO, J. L. R.; SANTOS, N. P. S.; TORRES, T. $\mathrm{S}$. Genetic parameters for carcass traits and body size in sheep for meat production. Tropical Animal Health and Production, Edinburgh, v. 48, n. 1, p. 215-218, 2015.

FIGUEIREDO FILHO, L. A. S.; SARMENTO, J. L. R.; CAMPELO, J. E. G.; SANTOS, N. P. S.; SOUSA JÚNIOR, A. Medidas de características da carcaça por meio de ultrassonografia em caprinos. Revista Brasileira de Saúde e Produção Animal, Salvador, v. 13, n. 3, p. 804-814, 2012.

FIGUEIREDO FILHO, L. A. S.; SENA, L. S.; SANTOS, G. V.; GUIMARÃES, F. F.; PIRES, L. C.; SARMENTO, J. L. R. Associação entre tamanho corporal, carcaça e peso vivo de ovelhas da raça Santa Inês. In: SIMPÓSIO DA SOCIEDADE BRASILEIRA DE MELHORAMENTO ANIMAL, 10., 2013, Uberaba. Anais... Uberaba: Sociedade Brasileira de Melhoramento Animal, 2013. CD-ROM.

GINÉ, G. A. F.; FREITAS, R. T. F.; OLIVEIRA, A. I. G.; PEREIRA, I. G.; GONÇALVES, T. M. Estimativa de parâmetros genéticos para características de carcaça em um rebanho de suínos Large White. Revista Brasileira de Zootecnia, Viçosa, MG, v. 33, n. 2, p. 337-343, 2004.

KARAMICHOU, E.; MERRELL, B. G.; MURRAY, W. A.; SIMM, G.; BISHOP, S. C. Selection for carcass quality in hill sheep measured by X-ray computer tomography. Animal, Cambridge, v. 1, n. 1, p. 3-11, 2007.

LIMA NETO, H. R.; BERGMAN, J. A. G.; GONÇALVES, T. M.; ARAÚJO, F. R. C.; BEZERRA, L. A. F.; SAIZ, R. D.; LÔBO, R. B.; SILVA, M. A. Parâmetros genéticos para características de carcaça avaliadas por ultrassonografia em bovinos da raça Guzerá. Arquivo Brasileiro de Medicina Veterinária e Zootecnia, Belo Horizonte, v. 61, n. 1, p. 251-258, 2009.

MEYER, K. WOMBAT - Digging deep for quantitative genetic analyses by restricted maximum likelihood. In: WORLD CONGRESS IN GENETICS APPLIED TO LIVESTOCK PRODUCTION, 8, 27-14, 2006, Belo Horizonte. Proceedings... Belo Horizonte: Communication, 2006. CD-ROM. 
MORTIMER, S. I.; VAN DER WERF, J. H. J.; JACOB, R. H.; PETHICK, D. W.; PEARCE, K. L.; WARNER, R. D.; GEESINK, G. H.; HOCKING EDWARDS, J. E.; GARDNER, G. E.; PONNAMPALAM, E. N.; KITESSA, S. M.; BALL, A. J.; HOPKINS, D. L. Preliminary estimates of genetic parameters for carcass and meat quality in Australian sheep. Animal Production Science, Melbourne, v. 50, n. 11-12, p. 1135-1144, 2010.

$\mathrm{ONO}, \mathrm{R} . \mathrm{K}$. Estimativas de parâmetros genéticos para características de crescimento e de carcaça em ovinos de corte. 2011. Dissertação (Mestrado em Genética e Melhoramento Animal) - Universidade Estadual Paulista, Faculdade de Ciências Agrárias e Veterinárias, Jaboticabal.

PEREIRA, J. C. C. Melhoramento genético aplicado à produção animal. 4. ed. Belo Horizonte: FEPMVZ Editora, 2004. 609 p.

PINHEIRO, R. S. B.; JORGE, A. M. Medidas biométricas obtidas in vivo e na carcaça de ovelhas de descarte em diferentes estágios fisiológicos. Revista Brasileira de Zootecnia, Viçosa, MG, v. 39, n. 2, p. 440-445, 2010.

PINHEIRO, R. S. B.; JORGE, A. M.; PARIZ, C. M.; YOKOO, M. J. I. Medidas repetidas no tempo realizadas por ultrassom em ovelhas de descarte em diferentes estágios fisiológicos. Semina: Ciências Agrárias, Londrina, v. 35, n. 4, p. 2739-2748, 2014. Suplemento.

PINHEIRO, R. S. B.; JORGE, A. M.; YOKOO, M. J. Correlações entre medidas determinadas in vivo por ultrassom e na carcaça de ovelhas de descarte. Revista Brasileira de Zootecnia, Viçosa, MG, v. 39, n. 5, p. 11611167, 2010.

SALAKO, A. E. Application of morphological indices in the assessment of type and function in sheep. International Journal of Morphology, Temuco, v. 24, n. 1, p. 13-18, 2006.
SARMENTO, J. L. R.; TORRES, R. A.; SOUSA, W. H.; PEREIRA, C. S.; LOPES, P. S.; BREDA, F. C. Estimação de parâmetros genéticos para características de crescimento de ovinos Santa Inês utilizando modelos uni e multicaracterísticas. Arquivo Brasileiro de Medicina Veterinária e Zootecnia, Belo Horizonte, v. 58, n. 4, p. 581-589, 2006.

SILVA, N. V.; FRAGA, A. B.; ARAÚJO FILHO, J. T.; CAVALCANTI NETO, C.; SILVA, F. L.; COSTA, P. P. S.; LIRA JÚNIOR, W. B. Caracterização morfométrica de ovinos deslanados Cabugi e Morada Nova. Revista Científica de Produção Animal, Areia, v. 9, n. 1, p. 6575, 2007.

SUGUISAWA, L.; MARQUES, A. C. W.; BARDI, A. E.; FAUSTO, D. Utilização da ultra-sonografia como ferramenta para padronização de carcaças comerciais. Tecnologia \& Ciência Agropecuária, João Pessoa, v. 3, n. 4, p. 55-65, 2009.

VICINI, L. Análise multivariada da teoria à prática. 2005. Monografia (Trabalho de Conclusão de Curso de Especialização em Estatística) - Universidade Federal de Santa Maria, Santa Maria.

WILSON, D. E.; ROUSE, G. H.; HAYS, C. L. Carcass EPDs from Angus heifer real-time ultrasound scan. Ames: Cooperative Extention Service, Iowa State University, 2001. 122 p. Available at: <http://www.extension.iastate. edu/Pages/ansci/beefreports/asl1736.pdf $>$. Accessed at: 27 feb. 2016.

YOKOO, M. J.; ALBUQUERQUE, L. G.; LÔBO, R. B.; BEZERRA, L. A. F.; ARAUJO, F. R. C.; SILVA, J. A. V.; SAINZ, R. D. Genetic and environmental factors affecting ultrasound measures of longissimus muscle area and backfat thickness in Nelore cattle. Livestock Science, Foulum, v. 117, n. 2, p. 147-154, 2008. 
